\title{
The worldwide trend to high participation higher education: dynamics of social stratification in inclusive systems
}

\author{
Simon Marginson ${ }^{1}$
}

Published online: 2 June 2016

(C) The Author(s) 2016. This article is published with open access at Springerlink.com

\begin{abstract}
Worldwide participation in higher education now includes one-third of the age cohort and is growing at an unprecedented rate. The tendency to rapid growth, leading towards high participation systems (HPS), has spread to most middle-income and some low-income countries. Though expansion of higher education requires threshold development of the state and the middle class, it is primarily powered not by economic growth but by the ambitions of families to advance or maintain social position. However, expansion is mostly not accompanied by more equal social access to elite institutions. The quality of mass higher education is often problematic. Societies vary in the extent of upward social mobility from low-socio-economic-status backgrounds. The paper explores the intersection between stratified social backgrounds and the stratifying structures in HPS. These differentiating structures include public/private distinctions in schooling and higher education, different fields of study, binary systems and tiered hierarchies of institutions, the vertical 'stretching' of stratification in competitive HPS, and the unequalising effects of tuition. Larger social inequalities set limits on what education can achieve. Countries with high mobility sustain a consensus about social equality, and value rigorous and autonomous systems of learning, assessment and selection in education.
\end{abstract}

Keywords Higher education · Educational participation · Enrolment growth · Mass education $\cdot$ Educational equality $\cdot$ Social stratification

Simon Marginson

s.marginson@ucl.ac.uk

1 UCL Institute of Education, University College London, 20 Bedford Way, London WC1H 0AL, UK 


\section{Introduction}

This article reviews the dynamics of high participation systems (HPS) of higher education, including the implications for social stratification and inequality. As measured by the UNESCO Gross Tertiary Enrolment Rate (GTER), ${ }^{1}$ worldwide participation is increasing very rapidly by historical standards, at $1 \%$ a year, and now constitutes one-third of the nominal school leaver age group. The tendency towards HPS, systems in which the GTER exceeds $50 \%$, has spread from the high-income and post-Soviet zones to include the overwhelming majority of middle-income countries, and some low-income countries. An expanding higher education system has become one of the norms of modernisation, pre-eminent as a social differentiator and allocator (Baker 2011), focus of the hopes of some families and then most families, and one part of the duty of states-like airports and roads, clean water, provincial hospitals and a viable banking system. This foreshadows a world in which knowledge, skills and personal agency will be much more widely distributed. Whether this is also a more equal world remains to be seen.

The article begins with conceptual framing. It argues that the ubiquitous growth of tertiary participation and the scramble for relative advantage within education are both sourced in the universal family desire for betterment, in social systems in which higher education functions as a positional good in a partly zero-sum world and can never fully satisfying all who enter it. The section that follows provides a 'birds-eye' empirical view of the world tendency to HPS and explores the drivers of that tendency. The article then looks more closely at the social patterning of outcomes in HPS, where the stratification of ambitious populations meets the stratified higher education systems that they use. It draws on recent research into social and educational stratification; and research into social, economic and educational inequalities. Most of this research is drawn from high-income countries, especially the USA. Social research is always partly specific to context in which the data are derived. However, there are insights in this research for all higher education systems, including emerging systems. The conclusion lists issues for middle- and low-income countries.

\section{The universal desire for betterment through education}

HPS of higher education are initiated, framed and regulated by states. Graduates are absorbed to a greater or lesser extent in national and global economies. However, the pivotal point where society meets higher education and drives its expansion is not public regulation or employer demand. As is further discussed below, though the social demand for higher educational opportunities is consistent and rising, the needs of states and employers for educational growth are partial and episodic; and neither agency intersects with higher education institutions on a daily basis. Nor is research the pivot, though it creates powerful global knowledge and sustains the social status and internal culture of elite universities. Rather, as first suggested by Trow (1973) in his essay on the transition from elite to mass-to-universal systems, the ongoing dynamism of higher education is powered by the ambitions of families for social position and of students for self-realisation. As Adam Smith remarked in The Wealth of Nations (1776), 'the desire of bettering our condition... comes with us from the womb and never leaves us till we go into the grave' (Smith 1979, p. 441). In contemporary societies, those desires, particularly the hopes of

\footnotetext{
1 The numerator of the GTER is total enrolment in 2-year programs and above; the denominator is the school leaver age cohort in the national population. The GTER is exaggerated by participation additional to the age cohort and appearing in the numerator, including migrants, international and mature age students, but facilitates comparisons between countries and over time.
} 
parents for children, have become primarily focused on formal education, which is seen as the privileged pathway to professional work. Family ambitions have no ultimate limiting factor and feed on themselves. Over time the social demand for higher education accumulates and tends towards the universal, as Trow predicted it would, and higher education provision becomes large, growing and increasingly ubiquitous.

Thus universal desires for social betterment are articulated through higher education systems that are themselves becoming universal. But the opportunities that education is meant to bring are not universal, not in capitalist societies that, regardless of whether they are low-, middle- or high-income, are stratified by unequal earnings and hierarchical power, in which at any given time, by definition, there is an absolute limit to the number of socially advantaged positions on offer. HPS of higher education can never bring every family what it seeks; and when participation becomes universal (as it already is in elementary and secondary education in many countries), at the margins of participation, students will gain no material betterment at all, though they may still gain forms of personal enlargement. In short, relative advantage is crucial. Socially, higher education functions as a positional good (Hirsch 1976; Marginson 1997) in which its sorting role is as important as the absolute opportunities that it brings. Starting positions are unequal and some pathways carry more value than others. Most families are deeply aware of this.

With families actively striving for position under conditions that they do not control, the formative effects of high education in society are experienced as a structure/agency dialectic. States and higher education institutions together structure higher education systems, stratifying the forms of provision and their cost and value. In the interaction between on the one hand structural forms and regulatory processes, and on the other hand the active agency of familieswho have little scope to directly influence the forms of educational differentiation, but work the structures that face them as well as they can, in their own interest-higher education sifts and sorts the population. Its precise role in social allocation, which varies from HPS to HPS, determines the extent to which higher education renders society more equal, or reproduces pre-existing inequalities. Here HPS vary in the 'slope' of their stratification of educational opportunities, and the autonomous power of institutions to shape social outcomes. Though all families pursue their own interests, they may find themselves located within HPS that either intensify competition and tightly limit educational and social success or within HPS that are organised on the basis of equal rights and the common good, and enhance the scope for social mobility. Within the constraints of resources, and social relations of power, between them states (especially) and institutions can increase the extent to which an HPS can have equalising effects.

Yet constraints of resources and class power matter. States in many low-income countries cannot build inclusive HPS. HPS in very unequal societies, such as today's United States (US), tend to be highly stratified, and strengthen not weaken the effects of social background in educational and social outcomes (Marginson 2016b).

\section{The trend to high participation higher education}

In $1971,9.9 \%$ of the world school leaver age cohort enrolled in tertiary education of 2 years or more in duration, ${ }^{2} 8.4 \%$ of women and $11.5 \%$ of men. Higher education was mostly a small elite sector, with most graduates becoming professionals or managers. The

\footnotetext{
2 'Tertiary education' includes both OECD Type 5A degrees of 3 years or more and shorter Type 5B programs of two years fulltime equivalent, for example US community colleges. Here, all such programmes are treated as 'higher education'.
} 
GTER exceeded $15 \%$ in only 19 countries, led by the US at $47.0 \%$, the world's first mass higher education system (UNESCO 2015). Less than two generations later, in 2013 the situation was totally different. Of the school leaver age cohort, $32.9 \%$ entered higher education, and the GTER for women $(34.5 \%)$ exceeded that of men $(31.3 \%)$. Graduates entered a wide range of occupations across and down the labour markets. Mass higher education was the global norm and was moving towards something more universal. No less than 102 countries had reached $15 \%$ and the GTER exceeded $50 \%$ in 51 countries, led by South Korea at $98.4 \%$. In 1971, South Korea's GTER had been only $7.2 \%$ (UNESCO 2015).

Between 1970 and 2013, the world number of tertiary students multiplied by 6.12 while global population multiplied by 1.93 (UNESCO 2015; World Bank 2015). From the late 1990s onwards, the expansion of participation accelerated, as Fig. 1 shows. An increase of $1 \%$ a year means $20 \%$ in 20 years. This suggests that the worldwide GTER will reach $50 \%$ inside the next generation, a staggering change.

This tendency to HPS is a process of combined and uneven development (Naidoo 2014). Participation is growing rapidly in the overwhelming majority of countries with the minimum capacity to mount a higher education system, except the small number like South Korea already near-universal levels. However, in 2013 regional GTERs varied from $76.6 \%$ in North America and Western Europe and $71.4 \%$ in Eastern Europe, to $22.8 \%$ in South Asia and only $8.2 \%$ in sub-Saharan Africa (Table 1).

Statistically, all high-income countries and most middle-income countries are tending towards or have exceeded the $50 \%$ mark. The first part of Fig. 1 shows growth in regions with aboveaverage participation. It includes Latin America and the Caribbean, where systems such as Venezuela, Chile and Argentina already exceed $50 \%$; and East Asia and the Pacific, demographically dominated by China, where enrolments have climbed rapidly in the last 15 years. Apart from China, the GTER exceeds $50 \%$ in all systems in East Asia. The second part of Fig. 1 shows the growth paths of regions with below-world-average GTERs. Again, however, the main tendency is growth. Many middle- and low-income countries have shared the long surge in enrolments. Though sub-Saharan Africa is the principal gap in mass higher education; its GTER has near doubled since 2000. South Asia was the other gap, and GTERs remain low in Pakistan and Bangladesh, but in the last decade the GTER has doubled in India to reach $23.9 \%$ in 2013, and also doubled in Pakistan. Only the Central Asian region breaks the pattern of rapid growth.

\section{Higher education in emerging countries}

The most rapidly growing higher education systems include those of Turkey, where from 2000 to 2012 the GTER rose from 25.3 to $69.4 \%$ (44.1\%), Albania (41.7\%), Cuba $(40.5 \%)$, Chile (37.2), Belarus (37.0\%) and Iran (36.0\%). It must be emphasised that the tendency to HPS extends to emerging nation states and has become integral to their emergence. China, India and Indonesia have three of the world's four largest populations. In China, the GTER rose from $3.1 \%$ in 1990 and $7.8 \%$ in 2000 to $29.7 \%$ in 2013. In India, it rose from 5.9 to $23.9 \%$ in $1990-2013$, and in Indonesia from 8.5 to $31.5 \%$ in 1990-2012 (UNESCO 2015).

The GTER is rising strongly in the great majority of countries where per capita GDP exceeds \$5000 USD (UNESCO 2015; World Bank 2015), and in some countries below that level. The low-income nations where higher education is yet to take off have middle classes that are too small and weak to demand educational opportunities or states that lack 

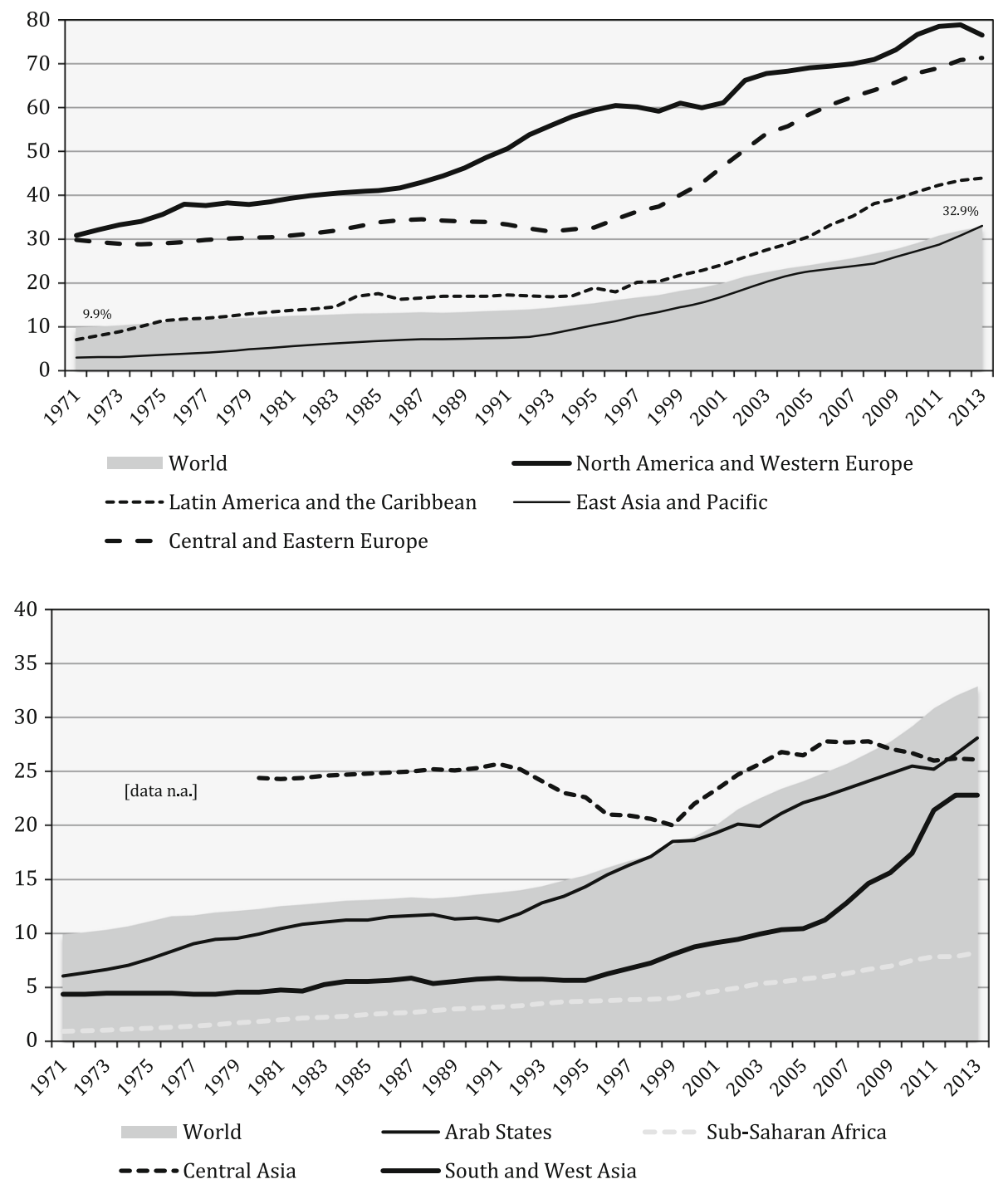

Fig. 1 Gross Tertiary Enrolment Ratio (\%), world and world regions: 1971-2013. [data n.a.] = regional data for Central Asia not available for 1971-1979. Source: Chart prepared by the author using data from UNESCO (2015)

the capacity for longer-term planning and/or tax-based financing of educational infrastructure. Table 2 lists the participation rate in 1971, 1980-2010 and 2013 in all nations with a per capita GDP of $\$ 5000-10,000$ in 2013 , in purchasing power parity (PPP) terms and constant 2011 prices, for which UNESCO provides data. The world average per capita GDP was $\$ 12,680$. There are data gaps, especially in Africa, but of the eighteen countries where 2013 data are available, the GTER exceeded $15 \%$ in fourteen, and in two it was 
Table 1 Gross Tertiary Enrolment Ratio (GTER) by world region: 1971, 1980, 1990 2000, 2010 and 2013. Source: Table prepared by author, using data from UNESCO (2015)

\begin{tabular}{llrrrrr}
\hline & $1971(\%)$ & 1980 & 1990 & 2000 & $2010(\%)$ & $2013(\%)$ \\
\hline World & 9.9 & 12.3 & 13.6 & 19.0 & 29.3 & 32.9 \\
North America and Western Europe & 30.8 & 38.5 & 48.6 & 60.0 & 76.9 & 76.6 \\
Central and Eastern Europe & 29.8 & 30.4 & 33.9 & 42.8 & 67.9 & 71.4 \\
Latin American and the Caribbean & 7.0 & 13.3 & 16.9 & 22.8 & 40.9 & 43.9 \\
East Asia and the Pacific & 2.9 & 5.1 & 7.3 & 15.4 & 27.3 & 33.0 \\
Arab States & 6.0 & 9.9 & 11.4 & 18.6 & 25.5 & 38.1 \\
Central Asia & n.a. & 24.4 & 25.3 & 22.0 & 26.7 & 26.1 \\
South and West Asia & 4.2 & 4.5 & 5.7 & 8.7 & 17.4 & 22.8 \\
Sub-Saharan Africa & 0.9 & 1.8 & 3.0 & 4.4 & 7.7 & 8.2 \\
\hline
\end{tabular}

First available GTER data for Central Asia are for 1980, at $24.4 \%$

n.a. not available

above $50 \%$. Only the African countries, Swaziland and the Republic of the Congo, were still waiting for participation to climb. Of the countries with GTER data for both 2000 and 2013, all but two experienced rapid growth. Georgia was the only case of decline but its GTER remained at the world average.

\section{Drivers of growth}

What are the drivers of the worldwide trend to HPS? The growth of participation is often represented as a function of the economic need for more skills and higher productivity in the markets for human capital. However, earnings are affected by many factors other than education (Piketty 2014, pp. 304-321); and beginning with Trow (1973), a succession of sociologists have debunked assumptions that participation rates are mediated by demand for educated labour or its value in rates of return (e.g. Schofer and Meyer 2005; Teichler 2009; Baker 2011). HPS coincide with economic modernisation everywhere, and demand for particular skills can affect graduate output, but total GTERs are rising sharply in HPS with wide variations in rates of economic growth and employment, and in industry/skill configurations (Marginson 2016a). While graduates enjoy measurable advantages over non-graduates, and often display unreasoning optimism about their prospects (Arum and Roksa 2014, p. 85 and 105; Hansen 2011, pp. 80-81), relations between higher education and work are fragmented (Robst 2007, p. 398; Roksa and Levey 2010, p. 391), the payoffs to mass higher education are unclear, and empirical evidence for human capital style decision-making, such as the use of rates of return data, is weak. Occupational status appears to be at least as stronger a motivator as earnings (e.g. Triventi 2013b, pp. 55-57; Thomsen et al. 2013, p. 471; Zhao 2012; Hu and Vargas 2015; Roksa 2005).

It is sometimes argued that the expansion of participation is explained by the credentialist strategies of educational institutions and the gateway strategies of occupational groups. Mass education institutions do have a vested interest in growth. But occupational licensing and credential structures vary, and supply side manoeuvres cannot explain a social tendency as powerful as HPS. Credentialism is a follower of educational expansion, rather than a leader. 
Table 2 Gross Tertiary Enrolment Ratio (GTER) in countries with per capita PPP gross domestic product of \$5000-10,000 per annum, constant 2011 USD: 1971, 2000 and 2013. Source: Table prepared by author, using data from World Bank (2015); UNESCO (2015)

\begin{tabular}{|c|c|c|c|c|}
\hline Country & $\begin{array}{l}\text { Per capita GDP } 2013 \\
\text { Constant } 2011 \text { USD }\end{array}$ & GTER $1971(\%)$ & GTER $2000(\%)$ & GTER $2013(\%)$ \\
\hline Albania & $\$ 9961$ & 13.9 & 13.8 & 58.5 \\
\hline Indonesia & $\$ 9729$ & 2.8 & 15.1 & 31.5 \\
\hline Sri Lanka & $\$ 9426$ & 1.1 & n.a. & 18.8 \\
\hline Jamaica & $\$ 8607$ & 5.2 & 15.4 & 28.7 \\
\hline Ukraine & $\$ 8338$ & 41.2 & 48.7 & 79.0 \\
\hline Belize & $\$ 8215$ & 1.0 & n.a. & 25.9 \\
\hline Paraguay & $\$ 7833$ & 4.4 & 15.7 & 35.1 \\
\hline Armenia & $\$ 7527$ & n.a. & 34.9 & 46.1 \\
\hline El Salvador & $\$ 7515$ & 3.7 & 20.7 & 25.9 \\
\hline Fiji & $\$ 7502$ & 1.0 & 15.8 & n.a. \\
\hline Guatemala & $\$ 7063$ & 3.3 & n.a. & 18.7 \\
\hline Morocco & $\$ 6967$ & 1.3 & 9.4 & 22.5 \\
\hline Georgia & $\$ 6930$ & n.a. & 37.8 & 33.1 \\
\hline Guyana & $\$ 6336$ & 1.6 & n.a. & 12.9 \\
\hline Philippines & $\$ 6326$ & 17.7 & n.a. & 33.8 \\
\hline Cabo Verde & $\$ 6232$ & n.a. & 1.9 & 22.8 \\
\hline Swaziland & $\$ 5998$ & 0.6 & 4.5 & 5.3 \\
\hline Bolivia & $\$ 5934$ & 8.1 & 34.9 & n.a. \\
\hline Republic of Congo & $\$ 5680$ & 0.7 & n.a. & 6.9 \\
\hline Samoa & $\$ 5502$ & 1.0 & 7.6 & n.a. \\
\hline India & $\$ 5244$ & 5.0 & 9.5 & 24.7 \\
\hline Vietnam & $\$ 5125$ & n.a. & 9.3 & 24.6 \\
\hline
\end{tabular}

There are no GTER data available for Namibia, Angola and Nigeria. Data for Uzbekistan (12.6\%) and Bosnia and Herzegovina (21.4\%) are available only for 2000, and for Bhutan (10.9 \%) only for 2013. These countries are all omitted from the table. In Indonesia, GTER data are for 1972 not 1971, and 2012 not 2013; in Paraguay data are for 2010 not 2013; in Fiji for 2003 not 2000

$P P P$ purchasing power parity, n.a. data not available

In most systems, governments regulate enrolment levels, sometimes in the private as well as public sectors. The common sense assumption is that system size is determined by policy, funding and regulation. However, states seem to play their largest role in the first growth of mass higher education, establishing sites and funding tuition and living costs to build social demand. As Trow (1973) argued, once higher education is entrenched as the route to a middle class life-once social demand for the positional good has been normalised-expansion secures a continuing momentum towards the universal. Families want higher education because it provides opportunities for upward social mobility, or at least is a means of maintaining status and a hedge against downward mobility. It also offers students prospects of self-formation (Marginson 2014) and self-actualisation. ${ }^{3}$ As the

\footnotetext{
${ }^{3}$ From Brendan Cantwell.
} 
frontier of participation advances, graduates maintain a labour market advantage over nongraduates. Though not all graduates have professional jobs when the GTER reaches $50 \%$ and more, and returns at the margin of participation decrease, the penalties attached to nonparticipation increase. Higher education becomes a defensive necessity. Once growth starts to feeds on itself, social demand for higher education is no longer created by states, except among marginal social groups. In countries with tuition fees, middle class families are more willing to share the costs, as they cannot afford to absent themselves from higher education. With the growing total cost of provision, many states introduce or increase tuition fees, though some also focus on improving the participation of under-represented groups. As HPS expand, apparently win-win issues of inclusion are easier to manage than are the always-awkward facts of system stratification.

Despite occasional concerns about 'over-education', states mostly support expansion at the HPS stage. Why, given that the demand for graduates is not clear-cut and higher education is expensive? HPS are the global policy norm, the creed of the World Bank and the Organisation for Economic Cooperation and Development (OECD), but this is not the driver, and nor is the economy. Rather, states are attuned to pressures from both social elites and growing middle classes who want better educational opportunities for their children. Some states respond to pressure from elites to nurture high-fee private schools and Ivy League universities, or maintain league table competitions in schooling that centre value on affluent suburbs (Dorling 2014, p. 28). Other states resist the rich and powerful. However, all states respond to pressure from below for educational expansion. Middle- and low-income countries achieve a mass-to-universal higher education system when that pressure from below become irresistible. This happens whether the nation-state is a contested democracy or a polity ruled by one party. In all HPS, it is no longer practical to impose an arbitrary limit on participation, as when higher education was a small elite system. Expanding higher education is also consistent with state political agendas. It is easier to create educational opportunities than jobs. It transfers responsibility for social outcomes from the state to educational institutions and families. UK and Australia even have 'demand-driven' systems (Kemp and Norton 2014) in which the number of publicly funded students is no longer capped - though the subsidy has been cut to manage costs. Cost transfers, from states with limited taxation revenues, to higher education institutions and/or families or graduates, are a common though not universal feature of the evolution of HPS.

Social demand for access is also magnified by the concentration of middle class agency in urban areas. Between 1970 and 2010, the worldwide proportion of people living in cities rose from 36.6 to $51.6 \%$. In emerging countries, urbanisation is driven by the movement from pre-capitalist rural areas to capitalist development in the cities. In China, the urban share climbed from $17.4 \%$ in 1970 to $49.2 \%$ in 2010, in Indonesia from 17.1 to $49.9 \%$, and in India from 19.8 to $30.9 \%$ (UNDESA 2012). When the largest countries are arranged in order of the extent of urbanisation, and their GTERs are graphed, the line of best fit suggests a strong association between urbanisation and the GTER (Marginson 2016a). Projections of major growth in the global middle classes ${ }^{4}$ by 2030 (e.g. Kharas and Gertz 2010) imply corresponding growth in demand for higher education. This is not to say all people living in cities are middle class or that aspirations for higher education are confined to such persons. The location of higher education in cities brings it within viewing distance of the whole urban population.

\footnotetext{
${ }^{4}$ Kharas and Gertz (2010) define 'middle class' persons as those with incomes of USD \$10-100 a day.
} 


\section{Social inclusion and stratification}

By definition, HPS higher education is more socially inclusive than elite higher education. The trend to HPS lifts the threshold of human agency, capability and rights (Sen 2000), provided that the higher education is suffiiciently formative to augment people's capabilities and/or social trajectories. In a high participation-based society, the average individual should be more comfortable with knowledge and information and other tools of reflexivity, more effective and creative in communication and civil organisation, more capable in dealing with corporations and governments, and potentially more proactive, flexible and productive at work. These are important gains. But does high participation higher education provide all young persons with equal educational opportunity? Does it render emerging countries more open and mobile, more socially and economically equal? These goals are more difficult to achieve.

First, not just schooling and higher education but prior social inequalities determine whether people from low-income families, remote locations or excluded minorities improve their social circumstances. Second, not all participation in HPS is of equal value. Higher education provides a stratified structure of opportunity, from elite universities and high-status professional degrees to the much larger number of places in mass education with uncertain outcomes. Third, students from affluent families often dominate the highvalue positions within higher education. Populations are socially stratified, HPS higher education is stratified, and outcomes are stratified. The objective of a policy designed to enhance equity is to modify the extent to which these forms of stratification reproduce each other, opening up the potential for upward social mobility via the HPS. Countries vary in the extent and type of stratification. HPS design makes a difference.

\section{Family background and educational stratification}

In HPS, the principal intrinsic limit to social equality of opportunity is the persistence of irreducible differences between families in economic, social and cultural resources. Policy can partly compensate for economic differences but cannot eliminate the potency of the family in cultural capital and social networks (Mountford-Zimdars and Sabbagh 2013). In a comparison of 11 European countries, Triventi (2013a) finds that 'individuals with better educated parents have a higher probability of attaining a degree from a top institution, of a higher standard, and with better occupational returns' (p. 499). In another four-nation study, he notes that the effects of social background on graduates' occupational outcomes vary by country in the extent of educational expansion, the social selectivity of education, the connections between education and the labour market, and 'the degree of institutional stratification in higher education' (Triventi 2013b, pp. 47-48).

... stratification of higher education refers to the degree of variation in selectivity, quality/prestige and labour market value of different courses, fields of study and institutions. All else being equal, the higher is the stratification of higher education, the more important is the role of social background in the occupational attainment process (Triventi 2013b, pp. 48-49),

The HPS trend increases the pool of graduates but does not increase the number of highvalue social outcomes that graduates can reach, which is determined by relations of social power and equality/inequality beyond education. Expansion exacerbates social competition in education (Arum et al. 2007, pp. 7-8), and this in turn enhances the effects of prior social inequalities. 'All else being equal, countries with a mass higher education system 
may be characterised by stronger competition among graduates in the transition to the labour market and, thus, by a larger effect of social background on occupational returns' (Triventi 2013b p. 48). The same trend to HPS, which enhances equity as inclusion, also increases the regressive effects of family background on educational and social outcomes. Thus, research on the growth of participation finds that as systems expand, class inequalities in access to elite higher education and career outcomes are not reduced (Arum et al. 2007, p. 3). Stratification effects trump the equalisation of educational quantity through growth. 'Qualitative differentiation replaces inequalities in the quantity of the education obtained' (Arum et al. 2007, p. 4). The national cases in Stratification in Higher Education (Shavit et al. 2007) demonstrate that as higher education expands, affluent families dominate the elite institutions. Newly participating social layers are largely confined to the sub-elite institutions where participation alone is not enough to generate strong social outcomes. The exceptions to these generalisations are when social mobility is unusually high, as in the 1960s/1970s in the US when higher education and social mobility grew together (Marginson 2016b), and/or when a determined policy effort is made by government to match growth with equalisation. Only under these circumstances is the natural tendency to greater inequality corrected.

Why does educational stratification tend to reinforce prior social inequalities, and why does expansion naturally enhance the effects of social background, or make no difference? Here, the point about the growth of HPS being driven by family aspirations for social position-for higher education as a positional good-rather than being driven by state ordering, or the needs of the economy, gains significance. HPS are populated by families that apply active agency to the contest for educational and social success, at every stage. Families with financial, social, cultural or political capitals bring those capitals to bear on education and continue to do so in the transition to work and beyond (Borgen 2015). Oxfam refers to 'opportunity hoarding', whereby 'social disparities become permanent'. Privileged groups 'take control of valuable resources and assets for their benefit', such as 'access to quality education' (Oxfam 2014, p. 20). The formal stratification of opportunities on the basis of institutional hierarchies and/or financial barriers provides points of purchase for family strategies. Whenever there is a hierarchy of value, families with prior social advantages are best placed to compete for scarce places or pathways that confer the greatest positional advantages (Triventi 2013b, p. 47; Lucas 2001, 2009). Educational differentiation allows the elite status of those 'born into privilege' to be protected (Arum et al. 2007, p. 5). HPS are regulated by the degree and type of selectivity and closure, within a common social regime of openness and inclusion. Social competition at the key points of transition and selection-entry to higher education, entry to professions and occupations-enables a fine-grained differentiation of the population, providing scope for stratified family capacities and strategic acumen.

Nevertheless, as suggested, this institutional reproduction of prior social inequalities is punctuated by moments (more in some systems than others) when policy, educational practices and student effort broaden the potential for upward mobility via education.

\section{Stratification between and within institutions}

The mechanisms of social and educational stratification are now examined more closely, before returning to HPS and social mobility. 


\section{Schooling}

Some nations pursue a comprehensive approach to schooling with low stratification in terms of quality. Affluent families in the United Kingdom (UK) can invest in high-fee private schools, which are especially successful in accessing selective universities. Spending per student is three times that in state schools. The UK also maintains a state school hierarchy, where stratification has shifted from the grammar/non-grammar distinction to market competition for entry into successful comprehensive schools. Undervaluing state schools increase the value of private education (Cheung and Egerton 2007, p. 218; Dorling 2014, p. 28 and pp. 40-41). Boliver $(2011,2013)$ traces unequal social access to selective UK universities since the 1960s. State school applicants for leading Russell Group universities and students from black and South Asian ethnic backgrounds 'were much less likely to receive offers of admission from Russell Group universities, in comparison with their equivalently qualified peers from private schools and the White ethnic group' (Boliver 2013, pp. 344-345). Private school students enjoyed an advantage equivalent to 'an additional B-grade A-level' over state school students with the same academic achievements (p. 358).

\section{Fields of study in higher education}

In HPS in which the institutional hierarchy is relatively 'flat', field of study can be more determining than institution attended of graduate earnings and status. Overall, field of study is more likely than institution to be associated with earnings differentials, especially in early years after graduation, while institutional prestige is more likely to be associated with occupational status and the likelihood of moving into managerial functions (e.g. Triventi 2013b, pp. 54-57; Hu and Vargas 2015), which may translate into later earnings advantages (Roksa and Levey 2010). Wolniak et al. (2008) suggest that the STEM disciplines reinforce the effects of prior family backgrounds, while business and education degrees provide more scope to change inherited inequalities (p. 135). Borgen (2015, p. 36) notes that when a high proportion of credentials are generic without clear vocational pathways, the hierarchy of institutions is more important as a distinguishing factor in driving family positional strategies. Significantly, this finding applies to both the marketdriven, mixed funded and stratified US system, and the publicly financed and 'flatter' Norwegian system.

\section{Vertical and horizontal diversity}

In contrast with schooling, in higher education some institutional stratification is inevitable, even in egalitarian Nordic societies. Concentrations of top researchers, and student places in high-status professional programmes, are scarce by nature. Bourdieu (1988) sees higher education systems as structured on a binary basis between selective institutions with high prestige that ration their places, and demand-driven mass institutions lacking prestige, that build volume so as to maximise their revenues and social presence. As the HPS expands, high-value student places shrink as a proportion of all places. Non-elite higher education increases in volume but average value declines, though the gap with nonparticipation remains. Sitting between the bifurcated elite and mass institutions are the ambiguous middle players, aspiring to the elite but lacking status and resources. States can use parcels of funding, the location of specific programmes or mission designations to 
expand the size of this group, for example by spreading middle-level value using the designation 'research university'.

National HPS vary in the 'steepness' of vertical stratification, and the extent to which horizontal distinctions based on institutional mission also function as vertical distinctions of status and resources. Emerging mass higher education often takes a binary form, partly to protect the mission (and clientele) of the academic universities. The second sector may emphasise technical-vocational education related to manufacturing, as in Germany, Korea or Taiwan, or middle professions such as teaching and/or local employment, as in the Netherlands. System expansion is also associated with a counter-tendency to academic drift whereby growing second sectors seeks to widen their horizons by acquiring a research role. In HPS, vertical diversity tends to trump horizontal diversity: given a choice, most institutions will move beyond the bounds of a non-research mission to the extent necessary to upgrade status. The movement of erstwhile second sectors into research helped to trigger the dissolution of binary systems in Australia (1988) and the UK (1992). At present, there are unresolved pressures for upward drift in the Netherlands. On the other hand, policy, regulation and custom may retain a stable division of labour, as in Germany and the California State University (CSU) campuses. The US CSUs are modelled as a ladder to the University of California (UC). German binary diversity is more horizontal. The fachhochschulen tend to have strong labour market outcomes (Teichler 2009).

If they choose, states can manage HPS on the basis of near equality of resources and a common mission, blurring the tendency to stratification of value by distributing capacity on a broad basis. Egalitarian system design has shaped universities in the Nordic world, Belgium, the Netherlands and the German-speaking countries, all of which sustain a rough equality in degree standing and research missions, though each HPS has a moderate informal prestige hierarchy. But except for Switzerland, none have ranked universities in the world top 30 (ARWU 2015). Here, egalitarian system design conflicts with the logic of 'World-Class Universities' (WCUs). WCUs are concentrations designed to build research strength and status at global level, attract academic migrants and foster cross-field industry innovations (Altbach and Salmi 2011). The WCU model, normalised by global rankings, affects policy in most countries (Hazelkorn 2011; Marginson 2011). Germany's Excellence Initiative and state-induced mergers in Denmark (Salmi 2009) were important departures from prior egalitarian HPS design. The WCU model is especially attractive to emerging countries that want to link to the world research system as soon as possible. Given the high and sustained investment required, one danger is that WCU building will be accompanied by neglect of the quality of mass higher education, for example the temptation to expand provision using MOOCs, other low-cost online distance learning, or foreign for-profit sectors. This policy danger seems chronic in high middle- and middle-income countries such as Russia, Malaysia and Kazakhstan, and also aspirant systems such as that of Vietnam, that are pressing for globally ranked universities. For example, in Russia the WCU goal is in direct tension with policy on regional capacity building.

\section{Public/private diversity}

Private sectors have more than one implication for social stratification. The US Ivy League universities are engines of social advantage. Soares (2007) finds that in 1988-2000, $64 \%$ of the students of Tier 1 institutions were from the top $10 \%$ American families in income (p. 167). This social composition reflects not just academic competition but high tuition and the use of supplementary entry criteria in the form of middle class cultural capital, for example applicants' records in music, elite sports and 'leadership'. Both modes of 
differentiation, finance and bio, are strategic opportunities for affluent families. The public sector UC Berkeley is equally selective in academic terms but runs a progressive tuition policy based on family income. Entry is free for $45 \%$ of students. Only $28 \%$ are from top $10 \%$ of households in income terms (Soares 2007, pp. 166-167; Douglass 2013, pp. 4-5). However, it is Ivy League degrees, not UC Berkeley degrees, that provide graduate entry into elite American firms in law, financing and business services (Rivera 1. 2011, 2015).

The private sector is positioned differently outside the US. Most HPS - Korea and the Philippines are partial exceptions - have few elite private institutions. National research universities are the focus of family ambition. Where there are large private sectors, as in Brazil, they provide mass education that expands freely in response to social demand without the constraint of public fiscal cost. While there are some rapidly growing public sectors, as in China, on average sectoral diversification facilitates the growth rate of HPS. However, mass private sectors carry problems of low and variable quality, especially forprofit colleges, which spend less of their revenue on teaching, and whose degrees lack potency in the labour market as the US case shows (Mettler 2014, pp. 87-110). There are also quality problems in mass public sectors in the many countries that underfund them, but there at least states can readily intervene. However, the HPS that manage quality best are those supported by a consensus on the norms of universal high-quality education that is shared by state and citizens. Formal 'quality assurance' cannot substitute for this.

\section{Effects of competition}

As suggested, in competitive HPS stratification tends to 'stretch' over time. Davies and Zarifa (2012) use Gini coefficients, Lorenz curves and other measures of inequality to compare the level of stratification in financial resources across 4-year institutions in Canada and the US over 1971-2006 (p. 143). There is a moderate-to-strong association between resource concentration and selectivity. In both nations, 'policy-makers are urging universities to remake themselves into highly differentiated, competitive, responsive, and entrepreneurial hubs of activity', with 'greater competition for revenue, whether in the form of tuition-paying clients, fund-raising, or research grants, and ... less bountiful and reliable government support' (pp. 144-145). Competition for status and resources is subject to cumulative advantage: strong institutions improve their relative position over time. 'Universities that are already older, established and wealthy enter new competitions for resources with prominent alumni networks, sizeable endowments, favourable locations, and strategic corporate ties' (p. 145). The US HPS is 'strikingly more stratified' than the Canadian in financial terms, and 'dominated by a small number of super-resourced, elite institutions that are highly distinct from the masses' and 'have pulled away from the pack' (pp. 150 and 154). However, in both HPS stratification has notably increased, especially in the last decade.

\section{Stratified structure and self-stratified agency}

Although almost all families want to maximise the social position of their children, family agency is not a constant over time, or between countries, or between socio-economic status (SES) groups. Confronted by the stratified structure of provision, families respond in a differentiated fashion that reflects varied material circumstances and cultural sets. Whereas upper-middle class families may put great effort into achieving the highest possible position within the HPS, low SES and remote students are less likely to nurture high ambitions, more likely to be deterred by cost, more likely to focus on secure and 
predictable employment-related paths rather than diffuse intellectual formation, more likely to believe they lack the cultural capital to survive and perform at university, and less familiar with performance and application strategies. Self-stratification happens even in free Nordic HPS (Thomsen et al. 2013, p. 457 and pp. 471-474). However, all else being equal, stratified HPS with price barriers tend to evoke larger self-stratification effects, and are more likely to empty out degree completion altogether in the bottom SES layers.

\section{'Under-matching' in applications}

In a census-level study of all 2008 applicants to US higher education, Hoxby and Avery (2013) track the applications of 'high-achieving' school students, ranked in the top $4 \%$ by SAT scores and grade point averages (p. 2). These students number 25,000-35,000 each year. In 2008, $17 \%$ were in the bottom family income quartile (pp. 14-15). The vast majority of these low-income high achievers did not apply to a 'selective college" 5 (i.e. higher education institution), though selective institutions charged lower tuition than many non-selective institutions, due to the provision of financial aid in selective institutions (pp. 5-6). The researchers found the application behaviour of most of the low-income high achievers differed greatly from that of their high-income counterparts. High-income high achievers followed advice to apply to a mix of highly selective and less selective institutions. Low-income high achievers opted for uniformly safe choices. Typically, they were from districts too small to support selective public high schools or a mass of fellow high achievers, and/or were unlikely to encounter a teacher, counsellor or student who had attended a selective institution.

Hoxby's and Avery's finding on the 'under-matching' of poor and remote students are replicated in Chankseliani (2013) study of rural students in Georgia. 'Of two applicants with the same general aptitude', the odds for an applicant from a mountainous village to apply to a least prestigious institution rather than a most prestigious one are about ' 12 times as high as the odds for an applicant from the capital' (pp. 438-439). In the UK, Boliver (2013) finds that 'applicants from lower class backgrounds and from state schools remained much less likely to apply to Russell Group universities than their comparably qualified counterparts from higher class backgrounds and private schools' (p. 344). Boliver refers to widespread perceptions that prestige universities are for the privately educated white upper-middle class (p. 347). When education is seen to belong to someone else, family aspirations and agency are diminished (Wilkinson and Pickett 2010, p. 113).

\section{Under-learning}

A more subtle form of self-stratification is uncovered by Arum and Roksa (2014). The extent to which higher education generates vocational capacity and intellectual formation is a function of student workloads. This is especially crucial for students who are the first in their families to enter higher education. Whereas affluent students carry the cultural capital of educated households, and enjoy later advantages also in the labour market, for many first-generation students, the HPS has more value to add. However, US data indicate that

\footnotetext{
5 'When we say 'selective college' in a generic way, we refer to colleges and universities that are in the categories from 'Very Competitive Plus' to 'Most Competitive' in Barron's Profiles of American Colleges. There were 236 such colleges in the 2008 edition. Together, these colleges have enrollments equal to 2.8 times the number of students who scored at or above the 90th percentile on the ACT or the SAT I' (Hoxby and Avery 2013, p. 2).
} 
study time is low relative to other countries, and falling (pp. 11-12). Arum and Roksa (2014) tracked 1600 students in 25 4-year higher education institutions. Generic academic competency tests found that after 4 years, the average student had moved from a starting $50 \%$ to the $68 \%$ mark, and $30 \%$ had failed to improve by even one per cent (p. 21 and pp. 37-38). Yet these students graduated, many with good grade point averages. Arum and Roksa argue that the shift to the notion of students as consumers, whose satisfaction and adjustment are uppermost, plus official emphases on extra-curricular activities and peer networking have conditioned a partial retreat from cognitive rigour. Student assessment of teaching and curricula affects faculty standing and shapes careers, so faculty demand less. The case studies in Armstrong and Hamilton (2013) illustrate the socially differential effects of these trends. Poorer students benefit least from higher education as a position and network game, in which outcomes are maximised by those with material advantages and cultural cunning. Poor students gain the most from higher education as hard work and intellectual formation. Yet Arum and Roksa (2014) find it is the students from highly selective institutions, the most affluent, that make the largest cognitive gains (pp. 42-44).

\section{Tuition-based stratification}

In HPS with significant tuition barriers, the external price structure becomes internalised in the form of self-stratification, accentuating prior social differences and affecting each of access, field of study, learning and completion (Arum et al. 2007, pp. 24-25). Free or low tuition, as in most of Northwest and Central Europe, eliminates this kind of self-stratification. When tuition fees are managed on the basis of income-contingent loans as in Australia and UK, the effects in self-stratification are minimised. Students do not pay at enrolment and discharge the loan in the form of increased tax obligations only when their earnings fall above the repayment threshold. This reduces the disincentive effects of tuition, and its socio-economic bias, except for earning students who pay in the year of study (Chapman 2014; Callender 2013). This facility is not available in the US, where higher education combines the differentiation of families on the basis of institutional selectivity with differentiation by financial cost.

The consequences for American social equality are explored in a large body of research and commentary on tuition barriers. Mettler (2014) notes that whereas in 1971 the average cost of attending 4-year public higher education institution was $42 \%$ of the income of bottom quintile families, by 2011 the figure was $114 \%$. For top-income quintile families, that average cost rose from 6 to $9 \%$ of income (p. 121). In many community colleges, families meet more than half the costs (p. 122) though the qualifications are often marginal (Roksa et al. 2007; Hansen 2011). Federal PELL grants cover a declining share of tuition (PELL Institute 2015, pp. 19-20). The US GTER hovers around $90 \%$, but there is steep stratification inside participation (Geiger 2015). In 2013, $77 \%$ of persons in the top family income quartile completed a degree by age 24 years, almost double the $40 \%$ in 1970 . In the bottom quartile, the graduation rate rose from 6 to $9 \%$ between 1970 and 2013. In the second bottom quartile, it rose from 11 to $17 \%$ (p. 31). Less than $40 \%$ had a degree by 24 years. Others dropped out, had 2-year diplomas of low value, or gained degrees slowly. US higher education 'stratifies people by income group rather than providing them with ladders of opportunity' (Mettler 2014, p. 8). US financial disincentives and self-stratification are compounded by larger social inequalities, which limit higher education's potential social effects: inherited wealth, income regulation, labour and capital markets, and state tax and transfers (Smeeding 2005). OECD data, using Gini coefficients, compare the level of income inequality before government taxes and transfers ('market-generated' 
inequality), to the level of inequality after taxes and transfers. The data for 2012 show that while in most countries government activity reduced market-generated inequality by $35-45 \%$, the US state did so by only $24 \%$, and Mexico by just $3 \%$ (OECD 2015).

When social inequality is very high, people from low SES backgrounds invest less in education and skills. They have less capacity to meet educational costs, less prospect of entering high-value institutions, and less prospect of turning degrees into careers. Over the generations, their relative position deteriorates (OECD 2014b, p. 12). The comparison by Cingano (2014) across the OECD countries suggests that a rise in income inequality of 6 Gini points reduces the probability of individuals with parents of low educational background being in tertiary education by 4 percentage points. However, 'inequality does not have any impact on the probability of graduating from tertiary education in the case of individuals with medium or high family background' (pp. 24-26).

\section{Social mobility and higher education}

What then is the extent of social mobility in different countries and what role does higher education play? Mobility is difficult to define, track and measure; and data on social mobility in a broad range of countries have yet to be developed. Studies are largely confined to the OECD nations. Corak (2012) measures social mobility in terms of the 'intergenerational elasticity in earnings' (IEE), the percentage difference in earnings in the child's generation associated with the percentage difference in the parent generation. 'An intergenerational elasticity in earnings of 0.6 tells us that if one father makes $100 \%$ more than another then the son of the high-income father will, as an adult, earn $60 \%$ more than the son of the relatively lower income father' (p. 2). Denmark, Norway and Finland each have an IEE of less than 0.20, whereas Canada is at 0.18, and Germany 0.32, France 0.41. The US is at 0.47 , indicating low social mobility (p. 10). Corak (2012) plots OECD nations' Gini coefficients against their IEEs. The line of best fit indicates a clear association between (a) high income inequality and (b) high IEE, meaning relatively low social mobility. However, these data not clarify the role of higher education in social mobility.

The OECD measures intergenerational educational mobility by comparing the odds of enrolling in tertiary education for two groups: those with at least one parent who attended tertiary education and those neither of whose parents attended tertiary education. Americans from tertiary educated families were 6.8 times more likely to access tertiary education than those from non-tertiary families. England (6.3) was similar. Scandinavia ranged from Finland (1.4) to Denmark (3.0). In South Korea mobility was 1.1 (OECD 2014a, p. 93). But these data on educational mobility are not linked to income or occupational status outcomes. Table 3 summarises the OECD and Corak (2012) data.

There is no study that conclusively establishes the role of higher education in mobility, though it is clear this varies by country. All that can be stated with confidence is that societies with egalitarian income distribution and high social mobility have HPS higher education, a relatively low level of private investment to secure positional advantage, and school systems with high and distributed learning achievement (OECD 2014c). This includes the Nordic countries, Benelux, Canada and South Korea. In contrast, the US has highly unequal incomes (Table 3, OECD 2014b; Piketty 2014; Saez 2013), low social mobility, and weak school learning achievement stratified by social background, plus very stratified higher education, high private sector tuition fees, growing public sector fees, and an HPS with high entry but much lower and socially skewed graduation. In 2011, the US 
Table 3 Income inequality (2012), two indicators of social mobility (2000s and 2012), and spending on tertiary education (2011), OECD countries with available data. Sources: Table prepared by author. Data from OECD (2014a, p. 93 and p. 232); OECD (2015); Corak (2012)

\begin{tabular}{|c|c|c|c|c|c|c|}
\hline & \multirow[t]{2}{*}{$\begin{array}{l}\text { Gini coefficient } \\
\text { after } \\
\text { tax/transfers } \\
(2012)\end{array}$} & \multirow[t]{2}{*}{$\begin{array}{l}\text { Ratio post-tax } \\
\text { income at } 90 / 10 \\
\text { percentiles }(2012)\end{array}$} & \multirow[t]{2}{*}{$\begin{array}{l}\text { Social } \\
\text { mobility 1: } \\
\text { IIE (2000s) }\end{array}$} & \multirow[t]{2}{*}{$\begin{array}{l}\text { Social } \\
\text { mobility } 2 \text { : } \\
\text { odds ratios } \\
(2012)\end{array}$} & \multicolumn{2}{|c|}{$\begin{array}{l}\text { Funding of tertiary } \\
\text { education as a } \\
\text { proportion of GDP } \\
\text { (2011) }\end{array}$} \\
\hline & & & & & $\begin{array}{l}\text { Public } \\
\text { sources } \\
\%\end{array}$ & $\begin{array}{l}\text { Private } \\
\text { sources } \\
\%\end{array}$ \\
\hline Denmark & 0.249 & 2.8 & 0.15 & 3.0 & 1.8 & 0.1 \\
\hline $\begin{array}{l}\text { Slovak } \\
\text { Republic }\end{array}$ & 0.250 & 3.2 & n.a. & n.a. & 0.8 & 0.2 \\
\hline Norway & 0.253 & 3.0 & 0.17 & 2.0 & 1.6 & 0.1 \\
\hline $\begin{array}{l}\text { Czech } \\
\text { Republic }\end{array}$ & 0.256 & 3.0 & n.a. & n.a. & 1.2 & 0.3 \\
\hline Finland & 0.260 & 3.1 & 0.18 & 1.4 & 1.9 & 0.1 \\
\hline Sweden & 0.274 & 3.3 & 0.27 & 2.3 & 1.6 & 0.2 \\
\hline Austria & 0.276 & 3.5 & n.a. & 5.1 & 1.4 & 0.1 \\
\hline Netherlands & 0.281 & 3.3 & n.a. & 2.8 & 1.3 & 0.5 \\
\hline Switzerland & 0.285 & 3.5 & n.a. & n.a. & 1.3 & n.a. \\
\hline Germany & 0.289 & 3.5 & 0.32 & 5.1 & 1.1 & 0.2 \\
\hline Poland & 0.298 & 3.9 & n.a. & 9.5 & 1.0 & 0.3 \\
\hline Ireland & 0.304 & 3.8 & n.a. & 3.3 & 1.2 & 0.3 \\
\hline France & 0.306 & 3.6 & 0.41 & 6.0 & 1.3 & 0.2 \\
\hline $\begin{array}{l}\text { South } \\
\text { Korea }\end{array}$ & 0.307 & n.a. & n.a. & 1.1 & 0.7 & 1.9 \\
\hline Canada & 0.315 & 4.2 & 0.19 & 2.6 & 1.6 & 1.2 \\
\hline Australia & 0.326 & 4.4 & 0.26 & 4.3 & 0.7 & 0.9 \\
\hline Italy & 0.327 & 4.4 & 0.50 & 9.5 & 0.8 & 0.2 \\
\hline Spain & 0.335 & 4.9 & 0.40 & 3.9 & 1.0 & 0.3 \\
\hline Estonia & 0.338 & 4.7 & n.a. & 4.7 & 1.4 & 0.3 \\
\hline $\begin{array}{l}\text { United } \\
\text { Kingdom }\end{array}$ & 0.350 & 4.2 & 0.50 & $6.4^{\mathrm{a}}$ & 0.9 & 0.3 \\
\hline $\begin{array}{l}\text { United } \\
\text { States }\end{array}$ & 0.390 & 6.2 & 0.47 & 6.8 & 0.9 & 1.8 \\
\hline Japan & n.a. & n.a. & 0.34 & 5.1 & 0.5 & 1.0 \\
\hline Chile & n.a. & n.a. & 0.52 & n.a. & 0.8 & 1.7 \\
\hline
\end{tabular}

'For example, an intergenerational elasticity in earnings of 0.6 tells us that if one father makes $100 \%$ more than another, then the son of the high-income father will, as an adult, earn $60 \%$ more than the son of the relatively lower income father' (Corak 2012, p. 2)

'Odds ratios' compare the odds of enrolling in tertiary education for two groups of 20-34 year olds-those with at least one parent who attended tertiary education (the numerator) and those neither of whose parents attended (the denominator; OECD 2014a, p. 93)

n.a. data not available, IIE Intergenerational Elasticity in Earnings

a England and Northern Ireland only 
GTER peaked at $95.3 \%$ of the age cohort. Yet because many students drop out before completion, and others stop at the 2-year diploma level, in the same year the graduation rate at degree level was only $38.9 \%$, a $56.4 \%$ gap between the tertiary participation rate and degree graduation rate (UNESCO 2015).

\section{National variations}

There are structural variations in the high social mobility countries. Nordic HPS have fairly 'flat' stratification, high public spending and no tuition. Canadian stratification and tuition are higher than in Europe but more modest than in the US. There is high spending from both public and private sources, while public policy emphasises citizen rights as in Europe. In South Korea, high social mobility (Table 3) is joined to a stratified HPS with emphasis on elite universities, and high private costs in other institutions. The tendency of the highly stratified HPS to exacerbate unequal social outcomes is cushioned by Korean equality in income determination and regional growth (Lee et al. 2012), a school system that ensures all graduates have advanced literacy, and East Asian not European/American educational culture (Marginson 2013). The results of the OECD (2014c) Programme of International Student Assessment show that all East Asian societies place exceptional value on learning; and the desire for educational success runs so deep in low SES families that private costs stratify ambition, participation and completion less than is the case in Europe and the US.

\section{Conclusions}

Education is a positional good subject to an absolute scarcity of high-value opportunities. Places in elite institutions and streams confer identifiable social advantage. These factors in themselves power the growing family investment of energy, time and (often) money in higher education, and drive the natural drift of that investment upwards to the leading institutions. However, the common public good is maximised when value differentials between institutions and fields of study are moderate, the 'floor' of educational quality in mass institutions is high, and the material and cultural conditions governing access and completion are equalised as far as practicable, consistent with human freedoms.

High participation higher education is becoming near-universal across the world. SubSaharan Africa is the last regional holdout. Yet in low- and middle-income countries, it is not enough to build greater social inclusion by growing quantitative participation and focusing on enhancing the relative opportunities of women and ethnic populations that have been under-represented or excluded. The more difficult issue is the relationship between educational inequality and socio-economic inequality. To ensure that the emerging HPS provides a broad pathway for social mobility, it is essential to maximise the autonomous allocative social power of higher education and build egalitarian structures within it. The Nordic countries provide the most advanced examples of broadly distributed social value in HPS higher education.

Five conditions strengthen the positive allocative social role of HPS. It must be said that these conditions absorb significant state resources and rest on a viable tax system, conditions not always present in low- or middle-income countries. First, the funding of higher education is largely from public sources. If tuition fees are charged, income-contingent loans are used and there is extra support for under-participating social groups. Second, private sector provision either plays a negligible role as in the Nordic world or is closely 
regulated to ensure social inclusion and quality of learning as in South Korea and Japan. Third, institutional stratification is modest. Research and professional training functions are broadly distributed. The nation may need to engage in WCU building to strengthen national science and elevate university prestige but WCUs should be coupled with policies ensuring a strong second tier and healthy mass higher education. Fourth, the state values rigorous learning and ensures that autonomous institutions, and processes of assessment and selection, are free from manipulation by powerful families (either directly or via the state) who seek competitive advantage. This maximises the opportunity for low SES students to move up through their own efforts. Finally, the scope of social regulation is extended to improve equity in graduate labour market selection.

However, policies designed to maximise social equality in and through higher education should be kept in perspective and balanced with other programmes. The old hubris that education alone can create socially just societies should be put aside. Though the evidence that has been mustered here on HPS, inequality and mobility is largely circumstantial, it suggests that more equal educational outcomes or greater mobility are hard to achieve in highly unequal societies. Higher education is not the only driver of social mobility. It is necessary but not sufficient, one part of a chain of institutional effects. If income is the measure of equality, then income determination, tax and transfers have more direct effects than does education sui generis. If social equality is measured in terms of occupational status, cultural capital, or personal agency, then higher education can have a larger effect than it can in relation to income distribution, provided that these qualities are not confined largely to students from socially advantaged backgrounds.

Above all, education can only function as an equaliser when this is supported by social consensus. Nordic egalitarianism in education and society is sustained by broad agreement on equality and mobility, grounded in a threshold level of trust and equality of respect, and consistently supported by state policy (Gärtner and Prado 2012).

Acknowledgments The term 'high participation systems' was coined by Anna Smolentseva. Thank you also to Brendan Cantwell.

Open Access This article is distributed under the terms of the Creative Commons Attribution 4.0 International License (http://creativecommons.org/licenses/by/4.0/), which permits unrestricted use, distribution, and reproduction in any medium, provided you give appropriate credit to the original author(s) and the source, provide a link to the Creative Commons license, and indicate if changes were made.

\section{References}

Academic Ranking of World Universities (ARWU). (2015). 2015 Academic Ranking of World Universities. Shanghai Jiao Tong University. http://www.shanghairanking.com.

Altbach, P., \& Salmi, J. (Eds.). (2011). The road academic excellence: The making of world-class research universities. Washington, DC: World Bank.

Armstrong, E., \& Hamilton, L. (2013). Paying for the party: How college maintains inequality. Cambridge, MA: Harvard University Press.

Arum, R., Gamoran, A., \& Shavit, Y. (2007). More inclusion than diversion: Expansion, differentiation and market structures in higher education. In Y. Shavit, R. Arum, \& A. Gamoran (Eds.), Stratification in higher education: A contemporary study (pp. 1-35). Stanford: Stanford University Press.

Arum, R., \& Roksa, J. (2014). Aspiring adults adrift: Tentative transitions of college graduates. Chicago: University of Chicago Press.

Baker, D. (2011). Forward and backward, horizontal and vertical: Transformation of occupational credentialing in the schooled society. Research in Social Stratification and Mobility, 29, 5-29. 
Boliver, V. (2011). Expansion, differentiation, and the persistence of social class inequalities in British higher education. Higher Education, 61, 229-242.

Boliver, V. (2013). How fair is access to more prestigious UK universities? The British Journal of Sociology, 64(2), 344-364.

Borgen, N. (2015). College quality and the positive selection hypothesis: The 'second filter' on family background in high-paid jobs. Research in Social Stratification and Mobility, 39, 32-47.

Bourdieu, P. (1988). Homo academicus. Stanford: Stanford University Press. (Trans. P. Collier).

Callender, C. (2013). The funding of part-time students. In D. Heller \& C. Callender (Eds.), Student financing of higher education: A comparative perspective (pp. 115-136). London: Routledge.

Chankseliani, M. (2013). Rural disadvantage in Georgian higher education Admissions: A mixed-methods study. Comparative Education Review, 57(3), 424-456.

Chapman, B. (2014). Income contingent loans: Background. In B. Chapman, T. Higgins, \& J. Stiglitz (Eds.), Income contingent loans: Theory, practice and prospects (pp. 12-28). Basingstoke and New York: Palgrave Macmillan.

Cheung, S., \& Egerton, R. (2007). Great Britain: Higher education expansion and reform-Changing educational inequalities. In Y. Shavit, R. Arum, \& A. Gamoran (Eds.), Stratification in higher education: A contemporary study (pp. 195-219). Stanford: Stanford University Press.

Cingano, F. (2014). Trends in income inequality and its impact on economic growth. OECD Social, Employment and Migration Working Papers, No. 163. Paris: OECD.

Corak, M. (2012). Inequality from generation to generation: The United States in comparison. Ottawa: Graduate School of Public and International Affairs, University of Ottawa.

Davies, S., \& Zarifa, D. (2012). The stratification of universities: Structural inequality in Canada and the United States. Research in Social Stratification and Mobility, 30, 143-158.

Dorling, D. (2014). Inequality and the 1\%. London: Verso.

Douglass, J. (2013). To grow or not to grow? A post-great recession synopsis of the political, financial, and social contract challenges facing the University of California. Research and Occasional Paper CSHE 15.13. Berkeley: Center for Studies in Higher Education, University of California Berkeley.

Gärtner, S., \& Prado, S. (2012). Inequality, trust and the welfare state: The Scandinavian model in the Swedish mirror. Högre seminariet, 7 November. Ekonomisk-historiska institutionen, Göteborgs universitet.

Geiger, R. (2015). Does higher education cause inequality? Essay review on Mettler (2014) and Armstrong and Hamilton (2013). American Journal of Education, 121(2), 299-310.

Hansen, H. (2011). Rethinking certification theory and the educational development of the United States and Germany. Research in Social Stratification and Mobility, 29, 31-55.

Hazelkorn, E. (2011). Rankings and the reshaping of higher education: The battle for world-class excellence. Houndmills: Palgrave Macmillan.

Hirsch, F. (1976). Social limits to growth. Cambridge, MA.: Harvard University Press.

Hoxby, C., \& Avery, C. (2013). The missing 'one-offs': The hidden supply of high-achieving, low-income students. Brookings Papers on Economic Activity, Spring.

$\mathrm{Hu}$, A., \& Vargas, N. (2015). Horizontal stratification of higher education in urban China. Higher Education,. doi:10.1007/s10734-014-9833-y.

Kemp, D., \& Norton, A. (2014). Review of the demand-driven funding system. Canberra: Australian government. https://docs.education.gov.au/system/files/doc/other/review_of_the_demand_driven_funding_ system_report_for_the_website.pdf.

Kharas, H., \& Gertz, G. (2010). The new global middle class: A cross-over from West to East. In C. Liu (Ed.), China's emerging middle class: Beyond economic transformation. Washington, DC: Brookings Institution Press.

Lee, H., Lee, M., \& Park, D. (2012). Growth policy and inequality in developing Asia: Lesson from Korea. ERIA Discussion Paper 2012-12.

Lucas, S. (2001). Effectively maintained inequality: Education transitions, track mobility, and social background effects. American Journal of Sociology, 106(6), 1642-1690.

Lucas, S. (2009). Stratification theory, socioeconomic background, and educational attainment: A formal analysis. Rationality and Society, 21, 459-511.

Marginson, S. (1997). Markets in education. Sydney: Allen \& Unwin.

Marginson, S. (2011). Imagining the global. In R. King, S. Marginson, \& R. Naidoo (Eds.), Handbook of higher education and globalization (pp. 10-39). Cheltenham: Edward Elgar.

Marginson, S. (2013). Emerging higher education in the Post-Confucian heritage zone. In D. Araya \& P. Marber (Eds.), Higher education in the global age (pp. 89-112). New York: Routledge.

Marginson, S. (2014). Student self-formation in international education. Journal of Studies in International Education, 18(1), 6-22. 
Marginson, S. (2016a). High participation systems of higher education. Journal of Higher Education, 87(2), $243-270$.

Marginson, S. (2016b). The dream is over: The Crisis of Clark Kerr's Californian Idea of Higher Education. Berkeley: University of California Press.

Mettler, S. (2014). Degrees of inequality: How the politics of higher education sabotaged the American dream. New York: Basic Books.

Mountford-Zimdars, A., \& Sabbagh, D. (2013). Fair access to higher education: A comparative perspective. Comparative Education Review, 57(3), 359-368.

Naidoo, R. (2014). Transnational higher education: Global wellbeing or new imperialism? Keynote presentation to the United Kingdom Forum for International Education Conference. London: UCL Institute of Education. 24 October.

Organisation for Economic Cooperation and Development (OECD). (2014a). Education at a glance 2014. Paris: OECD.

Organisation for Economic Cooperation and Development (OECD). (2014b). United States: Tackling high inequalities, creating opportunities for all. Paris: OECD.

Organisation for Economic Cooperation and Development (OECD). (2014c). PISA 2012 results in focus. What 15 year olds know and what they can do with what they know. Paris: OECD.

Organisation for Economic Cooperation and Development (OECD). (2015). Data on income distribution and poverty. http://stats.oecd.org/Index.aspx?DataSetCode=IDD.

Oxfam. (2014). Even it up: Time to end extreme inequality. Oxford: Oxfam GB.

Piketty, T. (2014). Capital in the twenty-first century. Cambridge, MA: Belknap Harvard University Press. (Trans. A. Goldhammer).

Rivera, L. (2011). Ivies, extracurriculars, and exclusion: Elite employers' use of educational credentials. Research in Social Stratification and Mobility, 29, 71-90.

Rivera, L. (2015). Pedigree: How elite students get elite jobs. Princeton, NJ: Princeton University Press.

Robst, J. (2007). Education and job match: The relatedness of college major and work. Economics of Education Review, 26, 397-407.

Roksa, J. (2005). Double disadvantage or blessing in disguise? Understanding the relationship between college major and employment sector. Sociology of Education, 78(3), 207-232.

Roksa, J., Grodsky, E., Arum, R., \& Gamoran, A. (2007). United States: Changes in higher education and social stratification. In Y. Shavit, R. Arum, \& A. Gamoran (Eds.), Stratification in higher education: A contemporary study (pp. 165-191). Stanford: Stanford University Press.

Roksa, J., \& Levey, T. (2010). What can you do with that degree? College major and occupational status of college graduates over time. Social Forces, 89(2), 389-416.

Saez, E. (2013). Striking it richer. The evolution of top incomes in the United States. Berkeley: University of California, Berkeley, Department of Economics. http://eml.berkeley.edu// saez/saez-UStopincomes2012.pdf.

Salmi, J. (2009). The challenge of establishing world-class universities. Washington: World Bank Publications.

Schofer, E., \& Meyer, J. (2005). The worldwide expansion of higher education in the twentieth century. American Sociological Review, 70, 898-920.

Sen, A. (2000). Development as freedom. New York: Basic Books.

Shavit, Y., Arum, R., \& Gamoran, A. (Eds.). (2007). Stratification in higher education: A comparative study. Stanford: Stanford University Press.

Smeeding, T. (2005). Public policy, economic inequality, and poverty: The United States in comparative perspective. Social Science Quarterly, 86, 955-983.

Smith, A. (1979). The Wealth of Nations. Harmondsworth: Penguin. (First published 1776).

Soares, J. (2007). The power of privilege: Yale and America's elite colleges. Stanford: Stanford University Press.

Teichler, U. (2009). Higher education and the world of work: Conceptual frameworks, comparative perspectives, empirical findings. Rotterdam: Sense Publishers.

The PELL Institute. (2015). Indicators of higher education equity in the United States. http://www. pellinstitute.org/downloads/publications-Indicators_of_Higher_Education_Equity_in_the_US_45_ Year_Trend_Report.pdf.

Thomsen, P., Munk, M., Eiberg-Madsen, M., \& Hansen, G. (2013). The educational strategies of Danish university students from professional and working class backgrounds. Comparative Education Review, $57(3), 457-480$.

Triventi, M. (2013a). Stratification in higher education and its relationship with social inequality: A comparative study of 11 European countries. European Sociological Review, 29(3), 489-502. 
Triventi, M. (2013b). The role of higher education stratification in the reproduction of social inequality in the labor market. Research in Social Stratification and Mobility, 32, 45-63.

Trow, M. (1973). Problems in the transition from elite to mass higher education. Berkeley, CA: Carnegie Commission on Higher Education.

United Nations Department of Educational and Social Affairs (UNDESA). (2012). World urbanization prospects: The 2011 revision. New York: United Nations.

United Nations Educational, Social and Cultural Organization (UNESCO). (2015). UNESCO Institute for Statistics data on education. http://data.uis.unesco.org/.

Wilkinson, R., \& Pickett, K. (2010). The spirit level: Why equality is better for everyone. London: Penguin.

Wolniak, G., Seifert, T., Reed, E., \& Pascarella, E. (2008). College majors and social mobility. Research in Social Stratification and Mobility, 26, 123-139.

World Bank. (2015). Data and statistics. http://data.worldbank.org.

Zhao, W. (2012). Economic inequality, status perceptions, and subjective well-being in China's transitional economy. Research in Social Stratification and Mobility, 30, 433-450. 